\title{
Algunas consideraciones sobre la legislación musulmana concernientes a los mozárabes
}

\section{Some considerations on Muslim Law concerning the Mozarabs}

\author{
Paulina LóPez Pita*
}

\begin{abstract}
RESUMEN
Aunque el estudio de los mozárabes ha dado lugar a una amplia producción historiográfica, en este trabajo se ponen de relieve diversos aspectos de la legislación musulmana concernientes a este grupo de población, denominado, junto a los judíos, dimmíes o gentes que gozaban de protección. Estas normas tomaron como base El Corán, la Sunna y los pactos o capitulaciones que les habían sido otorgados, variando con el tiempo algunas de ellas en diversos lugares. Estas disposiciones determinaron sus derechos y obligaciones, la forma en que debían comportarse, de manera especial respecto

a los musulmanes, bajo cuya autoridad decidieron quedarse a vivir. Este estudio trata de profundizar en el conocimiento del estado y la condición social en que vivieron los súbditos cristianos bajo dominio musulmán, tanto en la Península Ibérica como fuera de ella, y valorar si existió una convivencia auténtica entre musulmanes y cristianos.
\end{abstract}

\section{PALABRAS CLAVE}

Mozárabes, dimmíes, gentes del Libro, musulmanes, pacto, capitulación, El Corán.

\begin{abstract}
Although the study of the Mozarabs has given rise to a wide historiographic production, in this work are emphasized different aspects of the Muslim law concerning this group of population, named, together with the Jews, dimmíes or people who enjoyed protection. These rules were based in the Koran, the Sunnah and in the agreements or pacts that had been granted them, varying some of them in the course of time in different places. These agreements fixed their rights and duties, the way in which they had to behave, especially with respect to the Muslims, under whose authority they decided to live. This study tries to deepen in the knowledge of the state and the social condition in which the Christian subjects lived under Muslim authority, as much in the Iberian Peninsula as outside, and to value if an authentic coexistence existed among Muslims and Christians.
\end{abstract}

\section{KEY WORDS}

Mozarabs, dimmíes, people of the Scripture, Muslims, agreement, pact, The Koran.

* UNED. 
El problema de las minorías ha preocupado siempre a la historiografía española por lo que a este tema se le han dedicado numerosas investigaciones que han dado lugar a una amplia producción historiográfica desde el siglo XIX hasta el momento actual cuyas conclusiones son, a menudo, dispares. Hay que tener presente que los mozárabes fueron una comunidad heterogénea que fue cambiando en el transcurso del tiempo como lo hacía la propia sociedad en que se hallaban inmersos.

Así, por ejemplo, observamos respecto a la propia etimología del término «mozárabe» la existencia de diferentes interpretaciones dadas por los estudiosos que se han ocupado de este tema. En términos generales se ha venido repitiendo en la historiografía mozárabe que dicha denominación es de origen arábigo que fue impuesta por la población árabe a «tal linaje de súbditos», según expuso F.J. Simonet en el siglo XIX en su Historia de los mozárabes de España, aunque el mismo reconocía que «no lo había encontrado en ningún escritor hispano-muslímico". Los mozárabes, por su parte, aceptaron y usaron este nombre, denominándose con él, aún después de recobrada su libertad, en documentos públicos escritos en lengua arábiga ${ }^{1}$.

A comienzos del siglo XX, Á. González Palencia citando a dicho autor, repetía estas palabras: "sabido es hasta la saciedad que se dio el nombre de mozárabes a los cristianos que siguieron viviendo en territorios conquistados por los musulmanes, denominados musta'riba (plural de musta'rib), es decir, el que se asimila al árabe 0 arabizado².

Esta definición fue aceptada por otros investigadores entre los que podemos citar a I. De las Cagigas y a E. Levi-Provençal. Pero en la reciente historiografía encontramos opiniones distintas, para P. Chalmeta los mozárabes deben su apelativo a los cristianos del norte quienes mostrándoles cierto desprecio los denominaron mixti arabes, «no puros», es decir, mezclados con los árabes ${ }^{3}$. Idea mantenida asimismo por M. Epalza quien hace hincapié en el uso peyorativo del término que se hizo a partir del siglo XI en los reinos cristianos ${ }^{4}$.

El sentimiento de odio y enemistad que la población cristiana del norte de la península concibió desde el primer momento, contra aquellos otros cristianos que decidieron quedarse en poblaciones gobernadas por los musulmanes, denominados por M. ${ }^{a}$ J. Viguera «cristianos en al-Andalus ${ }^{5}$, fue puesto ya de relieve en el

1 SIMONET, F.J.: Historia de los mozárabes de España. Madrid, Turner, 1983, vol. 1, págs. VII-VIII.

2 GONZÁlEZ PALENCIA, A.: Los mozárabes de Toledo en los siglos XII y XIII. Madrid, I.V.D.J. 1930, vol. Preliminar, pág. 117. González Palencia nació en 1889 en Horcajo de Santiago (Cuenca) y murió en un lugar próximo en un accidente de coche en 1949. Fue Archivero del AHN de 1913 a 1927. En 1911 ganó por oposición la plaza de archivero en la delegación de hacienda de Toledo lo que aprovechó para estudiar la Historia de los Mozárabes.

3 CHALMETA, P.: «Mozárabes», Enciclopedia of Islam. New Edition, vol. VII, Leiden, New York, Ed. Brill, 1993, pág. 247.

4 EPALZA, M.: «Mozarabs: an Emblematic Christian Minority in Islamic al-Andalus», en JAYYUSI, S.K. (ed.): The Legacy of Muslim Spain. Leiden, Brill, 1994, págs. 149-170.

5 VIGUERA, M" . J.: «Mozárabes y cristianos de al-Andalus (s.VIII-XI)», en XI Congreso de Estudios Medievales, León, octubre 2007. 
siglo XVI por el predicador dominico fray Agustín Salucio (1523-1601), quien nos dio a conocer la opinión que de ellos se tenía en el Siglo de Oro, exponiendo así: "La población cristiana, que unidos por su fe presentaron resistencia contra los musulmanes, concibieron tal odio y enemistad contra los otros cristianos que se quedaron en los lugares a la obediencia de los moros", que, como dicen algunos historiadores, los comenzaron a llamar "Mistos o Metis", dándoles en rostro la mescla de su religión, como hombres que, honrándose con el nombre de cristianos, toda la fe y lealtad y afección era con los moros.

Produciéndose un verdadero enfrentamiento entre unos y otros cristianos, de manera especial, por que los Metis defendían que la consideración de la Religión no era necesaria para poder reinar; por lo que fueron considerados como «falsos $y$ fríos cristianos, sin zelo ni amor de religión, que estando mezclados y obedientes a los árabes por su escusa y loca justificación, les otorgaron una fidelidad y obediencia»; ya que incluso, trataron de persuadir a los demás cristianos para que se rindiesen y estuviesen "en paz y sosiego debaxo de su nuevo señor y Rey, debiéndose contentar con que les fuese permitido gozar de sus bienes", por lo que también llegaron a ser menospreciados por los mismos musulmanes que les tenían por viles y malos, como hombres que se habían sujetado a gente infiel por estimar más la posesión de sus bienes que la defensa de su religión ${ }^{6}$.

Por otra parte, D. Urvoy, reconociendo que el vocablo «mozárabe» es eminentemente ambiguo, opina que fueron los propios mozárabes quienes movidos por su afán de adoptar la lengua y civilización árabe como hicieron los cristianos de al-Andalus y sus homólogos de Siria, de Mesopotamia o de Egipto, se auto denominaron muta'arriba, es decir, receptores del título de árabes ${ }^{7}$. Idea que ya planteó Américo Castro afirmando que sometidos al Islam quedaron grandes masas de cristianos, que continuaron viviendo bajo la tolerancia musulmana durante cuatro siglos hasta que las tribus africanas, Almorávides y Almohades, terminaron con ese pueblo, cristiano por la fe, y musulmán en cuanto a ciertas tendencias y disposiciones de su vida interior, por lo que se llamaron a sí mismos mozárabes, o sea, arabizados $^{8}$. Opinión mantenida también por V. Cantarino para quien no es probable que los cristianos del Norte hayan sido los primeros en emplear este término y piensa que fueron los mismos mozárabes quienes lo introdujeron teniendo, sin duda, un significado peyorativo, de colaborador o simpatizante 9 .

Sin embargo, los escritores hispanoárabes prefirieron designar a los cristianos sometidos de al-Andalus con los términos nasara, nazarenos, rum, romanos, dim-

6 LÓPEZ ESTRADA, F.: «Dos tratados de los siglos XVI y XVII sobre los Mozárabes», en Al-AndaIus, 16, 1951, págs: 339-341. En el segundo de los tratados cuyo autor es desconocido, se recoge la opinión de Garibay, Alcocer o Pisa quienes afirmaban que el término «mozárabe» derivaba de Muza que quiso perpetuar su nombre en este grupo, pág: 345 .

7 URVOY, D.: «Les aspects symboliques du vocable «mozarabe», en Studia Islamica, 78, 1951, págs. 117-153.

8 CASTRO, A.: La realidad histórica de España. México, Porrua, 1996, pág. 179.

9 CANTARINO, V.: Entre monjes y musulmanes. El conflicto que fue España. Madrid, Alhambra, 1978, pág. 109. 
miyun, gentes protegidas, mu'ahadun, población bajo pacto, mu'ahid, confederado, o agam, no árabes, extranjeros; teniendo cada uno de estos términos un matiz distinto ya que rum hacia referencia a los cristianos libres occidentales, nasra se utilizaba para designar a los cristianos que vivían en la España Musulmana, o dimmí, término que llevaba implícito el pago de tributos a los que estaban obligados los cristianos que vivían bajo dominio musulmán ${ }^{10}$.

Pero dejando al margen estas consideraciones, así como la índole de la cuestión mozárabe: religiosa, nacional, cultural o social, analizada por D.A. Olstein en un reciente trabajo ${ }^{11}$, quisiera detenerme en analizar cual fue la situación en la que quedaron los cristianos que decidieron quedarse a vivir en territorios gobernados por los musulmanes fuera y dentro de la Península Ibérica para comprender y valorar el estado y la condición en que vivieron los mozárabes.

\section{MODO DE PROCEDER DE LOS MUSULMANES CON LOS PUEBLOS DOMINADOS}

Sabido es que los musulmanes ocuparon con gran rapidez un extenso territorio después que salieron de Arabia a la muerte de Mahoma $^{12}$ y extendieron sus dominios sobre una gran cantidad de pueblos no árabes, encontrándose con una enorme diversidad religiosa y étnica, sobre la que, en principio, no tuvieron la intención de imponer la religión musulmana. Los conquistadores musulmanes ejercieron muy poca presión, o ninguna, para que las poblaciones que acababan de conquistar se convirtieran al Islam. Probablemente cualquier intento de conversión forzosa habría indignado a la población local, la cual, como afirma H. Kennedy, habría reaccionado con hostilidad ${ }^{13}$. Los musulmanes consideraban a los cristianos y también a los judíos como "gentes del Libro», ahl al-Kitab, por ser depositarios de los libros de la Revelación, y ello les permitía poder elegir entre la conversión al Islam y la conservación de sus creencias. Muchos optaron por la conversión por las ventajas que esto suponía, pues no sólo consistía en un cambio de creencias sino que también llevaba consigo un cambio en el estatus jurídico, unido a que el ritual era rápido y sencillo, según expuso $\mathrm{P}$. Chalmeta en uno de sus trabajos en el que analiza diversos casos de conversión al Islam ${ }^{14}$. Varios son los estudios realizados por diversos autores en torno al proceso de islamización y de conversión en el ám-

10 PEÑARROJA TORREJÓN, L.: Cristianos bajo el Islam. Madrid, Gredos, 1993, págs: 52-53.

11 OLSTEIN, D.A.: La era Mozárabe. Los mozárabes de Toledo (siglos XII y XIII) en la historiografía, las fuentes y la historia. Salamanca, Universidad, 2006.

12 No procede en este el lugar explicar los motivos por lo que se produjo este rápido avance, por lo que remito a la obra de KENNEDY, H.: Las grandes conquistas árabes. Barcelona, Crítica, 2007, págs. $443-452$

13 KENNEDY, H.: Op. Cit. pág. 451.

14 CHALMETA, P.: «Le pasaje à l'Islam dans al-Andalus au X siècle», Actas Unión Europea Ar. e Isl. Málaga, 1986. Señala entre otras razones, no sólo las causas económicas y sociales a las que alude Lévi-Provençal, sino también motivos afectivos como podría ocurrir en el caso de las mujeres ya que el amor por un amante facilitaría la conversión de chicas jóvenes. 
bito de la España Musulmana que han sido recogidos en un reciente trabajo de T.F. Glick ${ }^{15}$.

El derecho musulmán ofrecía grandes ventajas y provechos al cristiano que abrazase el Islam, pues el que realizaba la profesión de fe al tiempo de la conquista quedaba desde ese mismo momento exento del pago de tributos, de la esclavitud de guerra y de la pérdida de bienes en que incurrían los que ponían resistencia. Asimismo, todas las infracciones que hubiesen cometido se les perdonarían por su conversión al Islam, por lo que muchos cristianos se sintieron atraídos por estas exenciones, y también porque su conversión era una oportunidad para escapar de las constricciones sociales existentes y poder entrar a formar parte de la nueva clase dirigente y tener la posibilidad de hacer carrera dentro del ejército. Fue, por tanto, la atracción y no la coerción lo que fomentó las conversiones al Islam ${ }^{16}$.

Aunque bien es verdad que el Fisco musulmán perdía mucho con las conversiones, era deber de los califas y emires promoverlas por todos los medios posibles. Advertido el califa Omar II de las cuantiosas pérdidas que le ocasionaban a las arcas del Tesoro Público las numerosas conversiones de los mozárabes de Egipto, respondió enérgicamente a su virrey que se tendría por dichoso si todos los dimmíes se hiciesen musulmanes, porque Alá había enviado a Mahoma por su Profeta no por recaudador de tributos. El número de estos nuevos musulmanes, muladíes, fue creciendo debido a los nacimientos de hijos habidos en matrimonios cuyo padre era musulmán. Sin embargo, en algunos lugares el espíritu de codicia predominó sobre el de proselitismo, empobreciendo, al margen de leyes y tratados, a la población cristiana.

No obstante, otros optaron por seguir su religión y pasaron a ser considerados como población protegida y amparada, dimmíes, por el Estado musulmán. Al aceptar este estatus las minorías quedaban excluidas de la participación en el poder político con la condición de quedar protegidos desde entonces en todos sus derechos personales y reales, en sus vidas y haciendas, en su religión y en sus leyes.

Las condiciones que les fueron impuestas por los musulmanes fueron fáciles de aceptar, y constituyeron, según afirma $\mathrm{H}$. Kennedy, un elemento clave en el triunfo de las conquistas árabes. A cambio estaban obligados al pago del tributo correspondiente a los dimmíes: yizya, impuesto personal, que variaba según la fortuna de los contribuyentes, su cuota podía fijarse en virtud del convenio cuando había capitulación, o se imponía por precepto legal en los territorios ganados por fuerza. Podía establecerse de forma individual o colectivamente, siendo en éste

15 GLICK, T.F. Paisajes de Conquista. Cambio cultural y geográfico en la España medieval. Valencia. PUV, 2007, págs. 77- 90. Al ocuparse de la conversión al Islam realiza un análisis de las opiniones de R. Bulliet sobre este aspecto; de M Epalza sobre la existencia de población mozárabe en Valencia; del proceso de islamización estudiado por P. Guichard; y de los trabajos de M. Acién Almansa sobre 'Umar ibn Hafsun.

16 KENNEDY, H.: Op. Cit. pág. 451. 
caso la comunidad la responsable de satisfacer la cantidad total. El pago de este impuesto solía realizarse personalmente y de forma humillante según un precepto coránico, algo oscuro, en virtud de lo mandado por Mahoma, pudiendo asistir a este acto todos cuantos lo deseasen. ${ }^{17}$

El segundo impuesto era el jaraiz, impuesto territorial, literalmente, rendimiento o producto de la tierra. Las tierras ganadas por capitulación eran propiamente las susceptibles del pago de este impuesto, pues de acuerdo con lo pactado quedaban en poder de los cristianos a cambio de satisfacer dicho tributo. Este impuesto no estaba sujeto a una tarifa fija en todos los países, como la yizya, sino que variaba según la naturaleza de los terrenos y según la proporción de las cosechas. Se pagaba por anualidades, debiéndose contar por años solares y no lunares. Su cobro era muy importante para los musulmanes por lo que suponía de ingreso para sus arcas.

No será hasta finales del siglo XI cuando comiencen a surgir quejas importantes por el aumento de las cargas fiscales, probablemente se pensó que la dominación árabe tendría menor duración y los mozárabes prefirieron pagar lo que se les exigía por temor a que sus ciudades y casas fueran destruidas y sus mujeres y niños vendidos como esclavos. En este aspecto los árabes se diferencian, entre otros de los mongoles, que destruyeron y arrasaron cuanto encontraban.

Por tanto, la cuestión religiosa no fue motivo de enfrentamiento entre vencedores y vencidos, aunque muchos derechos variaban si los pueblos habían sido conquistados a la fuerza o habían sido sometidos por capitulación. Las capitulaciones o pactos se realizaron siguiendo el prototipo del que se firmó después de la toma de Jerusalén por los árabes en febrero del año 638 , redactado en estos términos:

«En nombre de Dios, grande y misericordioso. Este es el tratado entre los cristianos de Jerusalén y Omar ibn al-Qattab. Cuando vinisteis en contra nuestra os pedimos vuestra protección para nosotros, nuestras familias, nuestras propiedades y la de nuestros correligionarios; e hicimos esta estipulación con vosotros por la que nos comprometimos a no construir ni en la ciudad ni en su suburbio nuevos monasterios, iglesias, conventos o eremitorios; no se restaurarán los que estén en ruina, ni los que se encuentran en barrios musulmanes de la ciudad; no se prohibirá a los musulmanes ni de día ni de noche entrar en nuestras iglesias, se abrirán sus puertas a los viajeros y a los que van de paso; se acogerá al musulmán que va de camino en nuestra casa dándole hospitalidad por tres noches, no habrá espías en nuestras iglesias ni en nuestras casas como tampoco se ocultará en ellas a ningún enemigo de ellos, no se enseñará el Corán a nuestros hijos, no se hará proselitismo de la religión cristiana, ni se pondrá obstáculos a la libre conversión al Is-

17 El dimmí puesto en pie entregaba el dinero al musulmán que estaba sentado sobre un trono; éste le cogía por el cuello al tiempo que le decía: “Oh dimmí, enemigo de Alá, paga la yizya», y los demás musulmanes que allí estaban empujaban al dimmí, provocando la risa y el divertemento de todos los que asistían a aquel acto. 
lam, se respetará a los musulmanes, y en las reuniones se les cederá el puesto, no se imitarán sus vestidos ni calzado, no se utilizará su modo de hablar, ni sus apellidos, no subiremos a caballo ni usaremos espada ni armas; no se llevarán inscripciones árabes en los anillos, ni se venderá vino, nos afeitaremos la cara y conservaremos en lo posible nuestro modo de vestir, usaremos cinturones en la cintura; no se pondrá la cruz sobre nuestras iglesias, ni se exhibirán en lugares públicos musulmanes ni las cruces ni los libros sagrados, se tocarán las campanas de las iglesias sin alboroto; no se recitarán las preces en alta voz en presencia de un musulmán, ni se llevarán en las procesiones ramos de palma o imágenes, ni se celebrarán funerales con clamor y candelas encendidas en las calles de los musulmanes ni en el mercado; no se poseerán esclavos ya tenidos por los musulmanes, ni se esconderá en la propia casa ni se golpeará a ningún musulmán. Prometemos guardar todo esto en nombre de nuestros correligionarios, pidiéndoos recibir en cambio vuestra protección y si violásemos alguna de las condiciones apuntadas, perderemos vuestra protección y quedaréis libres para tratarnos como enemigos $y$ rebeldes ${ }^{18}$.

Aunque este pacto sirvió como modelo para muchos otros que se firmaron con las comunidades cristianas, a menudo variaba según el modo en que se hubiera producido la conquista. En un principio, los mozárabes se encontraban diseminados por la España Musulmana, pero pronto prefirieron concentrarse en algunas ciudades de al-Andalus y constituyeron en ellas comunidades cristianas de importancia como sucedió en Toledo, Córdoba, Sevilla y Mérida con las que se habían firmado pactos. El más conocido de todos ellos es el que se firmó con el conde Teodomiro para el vasto territorio oriental que el gobernaba en la parte oriental de la Península. El conde aceptaba el patronato y la clientela del Profeta... con la condición de que no podría ser despojado de su señorío, ni podrían ser apartados los unos de los otros... ni violentados en su religión, ni quemadas sus iglesias, ni serían intimidados los que viviesen bajo la protección del conde.... Teodomiro se comprometía a no dar asilo a desertores ni a enemigos de los musulmanes.. ni ocultaría noticias de sus contrarios que supiese, y acuerda que en reconocimiento de su vasallaje, él y sus magnates pagarían cada año al gobierno musulmán un dinar, cuatro almudes de trigo, cuatro de cebada, etc... ${ }^{19}$.

La observancia fiel a los pactos está prescrita en El Corán,Sura 9, 4 sobre El arrepentimiento: «Se exceptúan los asociadores con quienes habéis concluido una alianza y no os han fallado en nada, ni han ayudado a nadie contra vosotros. Respetad vuestra alianza con ellos durante el plazo convenido. Dios ama a quienes Le temen ${ }^{20}$. Los pactos establecidos fueron, por lo general, humanos y favorables a los pueblos sometidos como lo exigían las fuerzas de las circunstancias. Los pri-

18 RIVERA RECIO, J.F.: «Formas de convivencia y heterodoxias en el primer siglo mozárabe», en Historia Mozárabe. I Congreso de Estudios mozárabes: Toledo, 1975. Toledo, I.E.V.M. de San Eugenio, 1978, págs. 6-8.

19 SIMONET, F.J. Op. Cit. págs: 52-53.

20 El CORÁN, ed. de J. CORTES, Madrid, ed. Nacional, 1979, pág. 252. 
vilegios de los pueblos o gentes del Libro, ahl al-Kitab, eran la norma y sólo se deterioraron en manos de gobernantes débiles que permitieron incumplimientos de los derechos de las minorías, o en manos de déspotas cuyo fanatismo condujo a contravenciones directa con la ley ${ }^{21}$.

\section{LEGISLACIÓN MUSULMANA RESPECTO A LOS CRISTIANOS SOMETIDOS}

Aunque no todos los cristianos sometidos gozaron de la misma situación, ni estaban sujetos a las misma normas, pues a menudo las reglas eran pactadas con los grupos locales por sus gobernantes particulares, pudiéndose ver con el paso del tiempo, ratificadas o modificadas por los nuevos gobernantes, podemos decir grosso modo que los musulmanes crearon para los dimmíes, tanto cristianos como judíos, una legislación especial, tomando como base El Corán, la Sunna y los pactos o capitulaciones otorgados desde los primeros tiempos del Islam. Con el tiempo este derecho fue modificado y aumentado con varias ordenanzas emitidas por los respectivos gobernantes, pero fue aplicado a todos los países que sometieron con sus armas. En cualquier caso, la condición social de los súbditos cristianos era muy inferior en derechos y prerrogativas a la de los súbditos musulmanes, encontrándose establecido en la ley musulmana, de modo expreso, el predominio de esta creencia. Según refiere F. Simonet, el califa Omar llegó a afirmar a propósito de los dimmíes: «nosotros no hemos pactado con ellos sino a condición de que pagen la yizya y de que vivan sujetos y humillados y así lo podemos comprobar si hacemos un repaso de lo establecido en la legislación musulmana ${ }^{22}$.

Entre los derechos otorgados a los pueblos cristianos sometidos por los musulmanes, ya por capitulación o por la fuerza, ocupa un lugar preferente el permiso para mantener y practicar el culto de acuerdo con su religión. En el primer tratado concertado entre Mahoma y los cristianos que vivían en Arabia, el primer derecho exigido por éstos fue que no se destruyesen sus iglesias ni se les violentara en el ejercicio de su religión; derecho que se expresó en los pactos establecidos posteriormente, como los firmados en Damasco y Egipto. No obstante, la Iglesia cristiana quedaba sometida a la supremacía de la religión musulmana, ya que según un jurisconsulto árabe «el islamismo es la más alta de las religiones».

Así pues, la Iglesia quedó supeditada en al-Andalus a la soberanía del Estado musulmán quien se arrogó algunos de los derechos y regalías de que gozaba la monarquía visigoda en orden a la elección de obispos, convocatoria de Concilios y otros puntos de la disciplina eclesiástica. A juicio de F.J. Simonet fueron muchos

21 GLICK, T. F.: Cristianos y musulmanes en la España medieval (711-1250). Madrid, Alianza Universidad, 1994, págs. 221-222.

22 SIMONTE, F.J.: Op. Cit. pág. 79. 
los estragos que se hicieron en los primeros años de la conquista, de manera especial en las poblaciones ganadas por la fuerza. En su huida, los fieles y Obispos se llevaron consigo muchas reliquias de santos que fueron depositadas más tarde por los Reyes de Asturias en la famosa Cámara Santa de Oviedo. La dominación musulmana dificultó las relaciones de la Iglesia con la Santa Sede de Roma pero no llegó a ocasionar un cisma y el Papa continuó ejerciendo su legítima autoridad e influencia sobre la España mozárabe ${ }^{23}$.

En los primeros años de la llegada de los musulmanes a España debieron de producirse mutuas influencias entre musulmanes y cristianos en cuestión religiosa. Hay que tener presente que sobre el elemento indígena, formado por hispano-romanos, godos y judíos, quienes habían visto cumplidas sus ansias de revancha por los malos años que habían pasado durante el gobierno visigodo, vinieron a juntarse beréberes africanos, yemeníes y qaysíes, los cuales traían consigo sus propias enemistades y continuos enfrentamientos, por lo que durante medio siglo se produjo un periodo de confusión. Además, poco tiempo después, llegó un contingente importante de población siria enviada por el califa de Damasco, Abd al-Malik, para ayudar a las fuerzas que luchaban en el norte de África. Estos sirios de raigambre tradicional cristiana y ligeramente islamizados fueron distribuidos por las diversas regiones hispanas de Levante y Andalucía, encontrando grandes semejanzas entre estos territorios y los que habían tenido en su patria; y ellos fueron un vehículo ideal para transportar a Occidente las doctrinas del ambiente de sus iglesias nestorianas ${ }^{24}$.

No debió de ser fácil para los mozárabes mantener su creencia en la Trinidad cuando el almuédano repetía constantemente la creencia islámica de la unicidad personal de Dios: "Sólo hay un Dios y a Él solo servirás». También por aquellas fechas se había infiltrado entre los mozárabes de Zaragoza la prohibición judaica de comer sangre de los animales, así como otras muchas prácticas, de tal forma que el Papa Adriano I (772-795) puso de relieve las heterodoxias insurgentes por entonces en España. Entre todos los movimientos heterodoxos fue el adopcionismo el que cobró especial significado ${ }^{25}$. Esta receptividad hacia las tendencias religiosas heterodoxos contribuye, afirma T.F. Glick, al retrato de un grupo, el mozárabe, culturalmente desorientado ${ }^{26}$. También para J. Hagerty, los mozárabes fueron proclives a la herejía y proporcionaban la justificación religiosa a la nueva realidad social de la comunidad cristiana de al-Andalus ${ }^{27}$.

23 SIMONET, F.J.: Op. Cit. pág. 131.

24 RIVERA RECIO, J.F.: Op. Cit. págs. 14-15.

25 El adopcionismo fue defendido por Elipando quien afirmaba que Jesús, Hijo de María, es solamente hijo adoptivo y no propio del Padre. Elipando tenía 30 años cuando se produjo la colonización de siria a Al-Andalus y sus adversarios le achacan que se formó en ese ambiente. Para los árabes, Cristo, hijo de la Virgen, era hijo de Dios pero simplemente por razón de la adopción y no por naturaleza.

26 GLICK, T.F.: Op. Cit. pág. 232. 1978.

27 HAGERTY, J.: Los cuervos de San Vicente: Escatología mozárabe. Madrid, Editora Nacional, 
Pero aunque el ejercicio de la religión cristiana estaba permitido, sin embargo quedó sujeto a muchas limitaciones, debiendo practicarse con discreción para no escandalizar a los musulmanes. En el pacto que el califa Omar estableció con los cristianos de Siria, éstos se hubieron de comprometer a no construir iglesias, ermitas, conventos ni casa patriarcal, ni a renovar los edificios que se derrumbasen en aquellos lugares donde vivían ni en sus contornos, y de manera especial aquellos otros que estuviesen ya levantados en lugares donde habitaban los musulmanes. Pero sobre este punto se observa alguna diversidad, ya que algunos pensaban que se les debía prohibir que las reparasen y revocasen únicamente; y según otro alfaquí podían ser reedificadas las iglesias que se hubiesen demolido injustamente, y no las que se hubiesen caído por sí mismas, en todo caso, sin aumento ni ensanche alguno, sobre el mismo suelo y empleando las mismas piedras y materiales antiguos ${ }^{28}$.

Cuando dentro de sus iglesias celebrasen el Oficio divino deberían realizarlo sin alzar la voz, y si tocaban las campanas deberían hacerlo con suavidad porque su sonido repugnaba a los musulmanes ${ }^{29}$. Se obligaban asimismo, a no salir en procesión con cruces $^{30}$, palmas, imágenes, cirios u otros objetos propios del culto cristiano por las calles y plazas frecuentadas por los musulmanes, ni tampoco en sus zocos; no obstante, hay constancia de que en al-Andalus en tiempos pacíficos, se permitía a los fieles cristianos concurrir a sus iglesias públicamente y ser convocados a los Oficios divinos al toque de las campanas. Las fuentes históricas nos cuentan la asistencia del poeta lbn Suhayd a una ceremonia nocturna celebrada por los cristianos ${ }^{31}$. Asimismo, se les obligaba a tener abiertas las puertas de las iglesias tanto de día como de noche para dar asilo y albergue a los transeúntes y viajeros musulmanes, dándoles hospedaje durante tres días.

En el tratado de Ibn 'Abdun Sevilla a comienzos del siglo XII, se prohíbe a las mujeres musulmanas que «entren en las abominables iglesias, porque los clérigos son libertinos, fornicadores y sodomitas. Asimismo, debe prohibirse a las mujeres francas que entren en las iglesias más que los días de fiesta, porque allí beben y fornican con los clérigos, y no hay uno de ellos que no tenga dos o más de estas mujeres con que acostarse», por lo que piensa que sería conveniente que los clérigos contrajesen matrimonio, como ocurría en Oriente ${ }^{32}$.

${ }^{28}$ Estudiado por BELLIN, F.A.: «Fetoua relatif à la condition des dizmmis et particulièrement des chrétiens en pays musulman, depuis l'établisement de l'islemisme jusqu'au milieu du VIII siècle de l'hegire, traduit de l'arabe». París, Journal Asiatique, XVIII, 1851.

${ }_{29}$ Cuando en 1453 los otomanos se adueñaron de Constantinopla, consideraron a los ciudadano griegos que vivían en Gálata miembros protegidos del Imperio a cambio de la sumisión y del pago de impuestos, y se les permitió mantener sus posesiones y «seguir con sus costumbres y ritos», excepto «tañer las campanas y proferir gritos». MANSEL, PH.: Constantinopla. La ciudad deseada por el mundo 1453-1924. Granada, Almed, 2005, págs. 30-31.

30 A finales del siglo XIX, en Turquía los cristianos solían cubrir la cruz con un velo cuando lo sacaban al exterior para asistir a algún entierro.

31 PEÑARROJA TORREJÓN, L. Op. Cit. pág. 60.

32 GARCÍA GÓMEZ, E. y LÉVI-PROVENÇAL, E.: Sevilla a comienzos del siglo XII. El tratado de Ibn 'Abdun. Sevilla, Biblioteca de Temas Sevillanos, 1981, pág. 150. 
No les estaba igualmente permitido levantar la voz cuando celebrasen un entierro, ni conducir a los difuntos con el rostro descubierto, ni transitar por las calles con la cruz levantada, con cirios encendidos y entonando los salmos y preces de costumbre por las calles en que habitaban los musulmanes hasta llegar a los cementerios que debían estar alejados de los lugares de enterramiento de los musulmanes ${ }^{33}$, aunque en determinadas épocas estos actos se realizaron públicamente con mayor libertad. En al-Andalus los prelados, ministros y monjes continuaron vistiendo sus hábitos e insignias correspondientes de acuerdo con su grado $u$ orden a la que perteneciesen.

Los cristianos no podían difundir sus enseñanzas religiosas de manera pública, y menos aún hacer prosélitos entre los musulmanes, debiendo, además, no impedir a ninguno de sus amigos abrazar el Islam. El conocido poeta e historiador andaluz Ibn Hazm, descendiente de mozárabes, trató de borrar de la memoria su origen cristiano y repite en una de sus obras que los cristianos no debían practicar en público ninguno de sus ritos ni mostrar a los musulmanes la cruz ni el vino, ni dejarles ver cosa alguna de su idolatría, pues de hacerlo así, quedaría roto y anulado el pacto bajo cuya protección vivían ${ }^{34}$.

Los dimmíes mozárabes debían tratar a los musulmanes con honor y reverencia, como a superiores que eran, levantándose cuando ellos se acercasen y cediéndoles los asientos cuando ellos quisiesen sentarse. No debían ocupar nunca puestos de preferencia en las reuniones, debiendo dejar a los musulmanes el mejor lugar en los paseos y en los caminos; nunca debían ser los primeros en saludar ni aún darles los buenos días con la forma arábiga sabáh aljair. Cuando estornudase un dimmíno debería decírsele «Dios tenga piedad de ti», sino «diríjate Alá por el mejor camino», o simplemente «Él te mejore».

Les estaba prohibido utilizar en su conversación expresiones usadas por los musulmanes, como los saludos assalam alaikum, "La paz sea sobre ti», porque Satán se apoderó de ellos por entero y les hizo olvidar el nombre de Dios $^{35}$; o marhaban, bienvenido, ni apellidarse con los prenombres usados por los árabes: usar sellos con caracteres arábigos; aprender la lengua árabe y enseñar $\mathrm{El}$ Corán a sus hijos, aunque algunas de estas prohibiciones se abolieron en la práctica para mayor provecho y crecimiento del Islam, como fue el empleo de la lengua árabe ${ }^{36}$. El cristiano que profiriese alguna injuria contra Mahoma sería castigado con la pena de muerte, sanción en la que se muestran unánimes to-

${ }^{33}$ Así consta en los pactos concertados por Mahoma y el Califa Omar con los cristianos de Arabia y de Siria. Véase Apéndice documental, F.J. SIMONET, Op.Cit. vol. 4, págs. 801-4.

${ }^{34}$ Ahmed ibn Said ibn Hazm nació en Córdoba en noviembre del año 994, y pertenecía a una familia de origen muladí recién convertida al Islam, pero en sus obras no dedicó demasiada atención a los mozárabes, al igual que otros ilustres historiadores muladíes, por el empeño que puso en que se olvidase su origen español y cristiano.

35 GARCÍA GÓMEZ, E. y LÉVI-PROVENÇAL, E.: Op. Cit. pág. 157.

36 El califa Hixam I (788-796) obligó a los hijos de los mozárabes al aprendizaje del árabe en las escuelas. RINCÓN ÁLVAREZ, M.: Mozárabes y mozarabías. Salamanca, Universidad, 2003, págs. 102103. 
dos los musulmanes ${ }^{37}$, que sólo podría perdonarse mostrándose su arrepentimiento y convirtiéndose al Islam.

Para no ser confundidos con los musulmanes y evitar que pudiesen recibir los honores y atenciones que a ellos correspondían, los dimmíes debían llevar vestidos diferentes, usando sus antiguos trajes, no pudiendo adoptar los usados por los musulmanes, ni mucho menos llevar las vestimentas de lujo de las autoridades, así como tampoco sus zapatos con rosetas. En al-Andalus, según el tratado de lbn 'Abdun, se indica que los cristianos deberán de llevar un signo por el que sean conocidos con el fin de humillarlos ${ }^{38}$ y no puedan confundirse con la población musulmana como ocurría en Oriente. Las mujeres cristianas se distinguían de las musulmanas, nos dice Ibn 'Abdun, por no llevar como ellas, el rostro tapado. Por su parte, F.J. Simonet afirma que las mujeres dimmíes debían llevar un zapato negro y otro blanco. Asimismo, los hombres debían raparse sólo la parte anterior de la cabeza y llevar el cabello de distinto modo ${ }^{39}$. Les estaba vedado ceñir espadas ni otras armas, así como fabricarlas o tenerlas en sus domicilios. Por cinturón debían usar un ceñidor de cuero, pelo o lana a diferencia del hizam que llevaban los musulmanes que solía ser una faja ricamente bordada.

Según las jurisprudencia musulmana, los cristianos debían llevar en la cabeza una especie de gorro o sombrero, negro y largo, o bien un birrete o un bonete largo y puntiagudo. $Y$ al entrar en los baños, tanto los hombres como las mujeres, debían de llevar en el cuello un sello de plomo o cobre, o una sonaja para no confundirse con los musulmanes ${ }^{40}$. Las vestimentas de los cristianos, al igual que la de los leprosos y los judíos, no deberían venderse, indica Ibn 'Abdun, a menos que se diese a conocer al comprador el origen ${ }^{41}$.

A los cristianos de ambos sexos les estaba prohibido montar a caballo por el carácter noble de este animal, debiendo utilizar mulas y asnos; también debían de abstenerse de usar sillas de montar y estribos, poniendo en su lugar albardas; y estaban obligados a cabalgar a la «mujeriega», es decir, de un solo lado. Debían circular por calles apartadas y extraviadas para evitar que pudiesen molestar a los musulmanes, a no ser que el viajero fuera demasiado viejo o inválido y necesitase realizar ese trayecto forzosamente. Además, debían procurar cabalgar lo menos posible, y si lo hacían, obligatoriamente se apearían al pasar delante de una mezquita.

Los oficios más viles debían ser realizados por los mozárabes, Ibn 'Abdun indica que los musulmanes no debían dar masajes a los cristianos, así como tam-

${ }^{37}$ Según el Kitab al-Sarim de Ibn Taimiyya (1266-1328), tomado de PEÑARROJA TORREJÓN, L.: Op. Cit. pág. 59.

${ }^{38}$ Esta noticia no la debió conocer F.J. Simonet pues indica literalmente que «no hay constancia de que en Al-Andalus se les obligase a llevar un distintivo, guiar, como ocurría en Oriente». Op. Cit. pág. 128.

${ }^{39}$ Los musulmanes solían raparse toda la cabeza, SIMONET, F.J. Op. Cit. pág. 80.

40 SIMONET, F.J.: Op. Cit. pág. 80, nota 2.

41 GARCÍA GÓMEZ. E. y LÉVI-PROVENÇAL, E.: Op. Cit. págs. 154-155 . 
poco debían tirar las basuras ni limpiar sus letrinas, por ser los judíos y los cristianos más indicados para estas tareas. Tampoco debería un musulmán cuidar de la caballería de un judío o un cristiano, ni servirle de acemilero, ni sujetarle el estribo, debiendo reprenderse a todo aquél musulmán que así lo hiciera ${ }^{42}$.

De igual modo, los cristianos no podían tener musulmanes a su servicio, ni por salario ni por cualquier otra recompensa, porque sería una humillación para éstos, ni esclavas musulmanas blancas o negras, ni tampoco adquirir esclavos de los que hubiesen tocado a los musulmanes en el botín. Y si el esclavo cristiano que tuviese un dimmí se hacía musulmán, no podría permanecer bajo el servicio de su señor, sino que sería vendido en el mercado al mejor postor ${ }^{43}$.

Aunque no estaba prohibido comer con los cristianos, en cierta ocasión al ser consultado el célebre imán Málic si ello era lícito, respondió que nunca cultivaría la amistad con un cristiano, pues como dijo cierto alfaquí para comer del mismo plato se requiere amistad. Por este motivo ningún mozárabe podría ocupar un cargo público ni particular que llevase consigo cierta responsabilidad y confianza, porque según advierte un alfaquí: «la wilaya, es decir, la investidura de los destinos públicos se deriva de la amistad».

No obstante, estas prescripciones a menudo no se cumplían pues hay constancia de que en las regiones orientales, Siria o Egipto, los sultanes confirieron a los dimmíes el desempeño de cargos importantes en la Hacienda pública o en la Administración ya que sus conocimientos eran muy superiores a los de los musulmanes, lo mismo que sucedió en Al-Andalus donde algunos nobles fueron designados por los califas para ocupar cargos de cierta importancia como dirigir las huestes y defender las plazas, conservando muchos de ellos sus títulos honoríficos ${ }^{44}$.

Las leyes musulmanas imponían también varias restricciones al derecho hereditario de los mozárabes. Mahoma había establecido: «El muslim no heredará al infiel , ni el infiel al muslim", por la diversidad de las religiones. Pero si un cristiano moría dejando acreedores musulmanes, éstos debían cobrar su débito de los bienes que aquél dejase, aunque consistiesen en vinos o puercos, cuya venta debía realizar un cadí por medio de un dimmí. Por su parte, los mozárabes podían testar y heredarse unos a otros según sus propias leyes.

Por lo que respecta a los matrimonios, la legislación musulmana, aunque con alguna repugnancia, permitía al musulmán casarse con mujeres libres y honradas, cristianas o judías, y no gentiles; los hijos habidos en estos matrimonios seguirían al padre en cuestión religiosa y en el pago de la yizya, mientras que su madre po-

42 GARCíA GÓMEZ, E. y LÉVI-PROVENÇAL, E.: Op. Cit. págs. 149-150.

${ }_{43}$ Cuando F.J. SIMONET escribe su obra Historia de los mozárabes de España a finales del siglo XIX, tiene constancia de que en Egipto y en Tánger había musulmanes que trabajaban al servicio de los cristianos. Situación que no estaba permitido en Turquía. Op. Cit. pág. 81.

${ }^{44}$ En diversos documentos mozárabes y latinos se mantiene el título de dominus, domina, santísimo, dado al obispo de Córdoba, el de serenísimo dado al Conde de la ciudad de Córdoba, y el de ilustrísimo, dado a Álvaro. Así lo cita el P. FLOREZ en la España Sagrada, tomado de SIMONET, F.J. Op. Cit. pág. 114. 
día darle alimentos prohibidos por el Islam así como llevarles a la iglesia; asimismo, se les permitía a cualquier musulmán libre o siervo tomar en concubinato, pero no en casamiento, esclavas cristianas o judías. Sin embargo, al cristiano no le estaba permitido contraer matrimonio ni tomar en concubinato a una mujer musulmana, so pena de incurrir en un gran delito. A los musulmanes les estaba prohibido intervenir como padrinos en los matrimonios celebrados entre los cristianos, aunque tuvieran entre ellos cualquier lazo familiar.

Los cristianos españoles conservaron bajo la dominación musulmana junto con la legislación visigoda o Fuero Juzgo, ciertas formas y manera de gobierno propios, rigiéndose por ésta en todo aquello que se relacionaba con su gobierno, exclusivamente municipal y local, sin perjuicio de las leyes musulmanas, situación que trataron de mantener posteriormente, incluso cuando continuaron viviendo en territorio ganado al Islam, como ocurrió después que el rey Alfonso VI se apoderase de Toledo en 1085, momento en el que los mozárabes de esa ciudad, que formaban una de las comunidades más numerosas, solicitaron ser juzgados por la Lex Gothorum o Fuorum Judicum.

En las poblaciones mozárabes de más importancia, el gobierno quedó en manos del comes o conde, título que habían llevado en tiempo de los visigodos los más altos funcionarios del orden civil. Su nombramiento había sido real pero en los pactos se estipuló que fuesen elegidos por los pueblos. Los condes eran asistidos por otros magistrados menores que ejercían sus funciones bajo su autoridad, muchas de cuyas denominaciones han pasado a nosotros con nombres arábigos, tal es el caso de vicario o veguer, cadí o juez, posteriormente, alcalde, almojarife o contador de hacienda, almotacén o encargado del control de pesas y medidas, alarife, perito en materia de edificaciones ${ }^{45}$, etc... Sabemos que el Conde de Córdoba alcanzó gran autoridad, y parece ser que fue considerado como la más alta autoridad de todos los cristianos de la España Musulmana, por lo que se le dio la denominación de «Conde de al-Andalus» o de «Príncipe de los cristianos sometidos», siendo admitido con frecuencia en la corte y entre los más allegados al califa, con cuya persona debía de tratar muchos casos y negocios de la administración.

En los juicios civiles y criminales, los dimmíes se regían por sus propias leyes y magistrados. La administración de justicia estaba en las comunidades mozárabes a cargo de un juez, llamado el «Juez de los Nazarenos» quien debía juzgar de acuerdo con el Evangelio. A veces, si así lo solicitaban los litigantes podía intervenir un juez musulmán, que aplicaría las leyes musulmanas, auque según un imán lo más adecuado es que renunciase a juzgarles. Los pleitos que surgiesen entre musulmanes y cristianos serían juzgados según las leyes musulmanas. Aunque la equidad de estos juicios estaba recomendada en El Corán cuando dice: «júzgalos según el mandamiento de Ala", celebrados los juicios, los cristianos eran inferiores respecto a los musulmanes, tal caso ocurría si un dimmí daba muerte a un musulmán que era casti-

45 Para SIMONET estos vocablos fueron introducidos en los reinos cristianos a través de los mozárabes, Op. Cit, pág. 132. 
gado con la pena de muerte, algo que no sucedía en caso contrario, porque se consideraba que no había provocado la muerte con alevosía y premeditación. Los jurisconsultos musulmanes recomendaban a los jueces ejercer su cargo en los atrios de las mezquitas, sentándose en un sitio ancho y capaz al que se pudiera acceder cómodamente, así como ser benigno con el humilde.

A pesar de todo, el dimmí podía perder el pacto de protección y seguridad que los musulmanes le habían otorgado, aunque sobre sus causas y motivos no hay acuerdo entre los jurisconsultos musulmanes. Para unos, bastaba infringir cualquiera de las condiciones, según era la opinión del citado lbn Hazm, como pecar con mujer musulmana, o dar asilo a enemigos del Islam; y según otros, solamente si no se hubiesen cumplido las de mayor importancia. Por consiguiente, discrepan de igual manera respecto al castigo que se les impondría, pues según los más benignos el dimmí castigado sería deportado a un país de su propia religión; pero según la opinión más corriente debían considerárseles como enemigos de guerra, y como tales muertos o hechos prisioneros.

\section{¿CÓMO FUE LA CONVIVENCIA ENTRE MUSULMANES Y MOZÁRABES?}

Los árabes en su expansión por Siria, Egipto y demás países orientales no introdujeron ninguna cultura, sino que, por el contrario, fueron adquiriendo enseñanzas de los pueblos indígenas que eran en su mayoría cristianos. Recordemos que en Siria a la llegada de los musulmanes florecía una importante escuela en Damasco en la que destacó San Juan Damasceno quien ejerció una notable influencia en la cultura arabo-oriental bajo el gobierno de los primeros califas. Y aunque el imperio musulmán echó profundas raíces en aquellas regiones donde existía una infinidad de razas y de idiomas, sin embargo, los pueblos cristianos de Oriente conservaron sus antiguos dialectos: siriaco, armenio, copto, etiópico y griego al menos en el uso de sus sacerdotes y sabios.

Asimismo, en la España musulmana la influencia de los mozárabes sobre sus dominadores fue aún mayor, y así las escuelas cristianas de Córdoba y Toledo, no sólo conservaron su antigua ciencia, sino que cooperaron eficazmente a la civilización de la España musulmana. A través de las obras de San Eulogio podemos apreciar como en la propia ciudad de Córdoba, capital de la España musulmana, subsistían a mediados del siglo IX las escuelas hispano cristianas. El autor de la Crónica Mozárabe, entre otros, vivió y trabajó en un mundo en el que las interacciones entre musulmanes y cristianos eran cotidianas y formales, y es evidente que se identificaba con los círculos de la clase dirigente musulmana cordobesa, sin perder por ello su identidad cristiana, y probablemente, su conocimiento de la historia y la política de alAndalus le hace pensar a $\mathrm{H}$. Kennedy que los musulmanes pudieron haberle empleado en la administración, como también sucedió con otros personajes en algunos lugares de Oriente ${ }^{46}$.

${ }^{46}$ KENNEDY, H.: Op. Cit. págs. 428-430. 
Para la transmisión de sus conocimientos a los árabes, fue preciso que los mozárabes aprendiesen la lengua árabe, ya que según F.J. Simonet, los árabes «por altivez o desidia repugnaban aprender los idiomas extranjeros». Además, la demanda del mercado debió de ser también un estímulo suficiente, como afirma T. Glick, para inducir a los mozárabes a aprender el árabe ${ }^{47}$. De esta forma, tanto en Oriente como en Occidente, pudieron comunicar a sus dominadores los tesoros, para ellos inaccesibles, de la ciencia griega y latina, haciendo traducciones al árabe de obras literarias y científicas de originales sirios, griegos y latinos ${ }^{48}$.

Para F.J. Simonet esta interrelación duró poco tiempo, únicamente el tiempo en que los musulmanes tuvieron necesidad de la población cristiana, con el tiempo, al aumentar su poder fueron creciendo las exigencias hacia los mozárabes, y con determinados pretextos fueron violando los pactos y fueros otorgados en los primeros momentos de su dominación en todos los países. La situación debió de ser difícil para los mozárabes de Málaga si tenemos en cuenta las palabras que el Papa Pascual II pronunció al dirigirse a ellos a comienzos del siglo XII: «Inter. Sarracenos tanquam Inter lupos et leones vivitis ${ }^{49}$. Posteriormente, Ibn Jaldún en el siglo XIV dejó constancia, según su parecer, de que entre todos los imperios ninguno había gobernado peor a sus pueblos que el árabe y afirma: «los árabes cuando subyugan a un pueblo, sólo piensan en enriquecerse desposeyendo a los vencidos; jamás intentan darles una buena administración. Para incrementar la renta que extraen del país conquistado, reemplazan ordinariamente las penas corporales por las pecuniarias. Por eso bajo la dominación de los árabes los delitos no cesan de aumentar»50.

La tolerancia musulmana hacia los cristianos disminuye a comienzos del siglo IX debido, entre otros factores, a lo sucedido en el año 818 en la revuelta del arrabal de Secunda en Córdoba, cuando comerciantes y artesanos se amotinaron y llegaron a cercar al emir, pero al ser derrotados el arrabal se convirtió en un campo de labranza y sus habitantes fueron enviados a Toledo, Fez y Alejandría; a la participación de los mozárabes en las revueltas fronterizas contra el emir; y a la intransigencia de los alfaquíes. Tal fue la situación para los mozárabes que en el año 826 Luis el Piadoso exhortaba a los mozárabes a seguir combatiendo al emir para lo cual les ofrecía ayuda militar, al tiempo que les ofrecía sus dominios por si deseaban abandonar al-Andalus. Un caso especial ocurrió en la ciudad de Toledo, donde los mozárabes se alinearon con la minoría árabe local en su lucha frente al califa de Córdoba, soportando las incidencias de estos enfrentamientos durante varios siglos ${ }^{51}$.

47 GLICK, T. F.: Cristianos y musulmanes, Op. Cit. pág. 232.

48 SIMONET, F.J. Op. Cit. tomo I, pág. XLVII

49 FLOREZ, E. España Sagrada. Madrid, 1747-1879, tomo XII, pág. 334.

50 IBN JALDÚN, «Prolegómenos», en Introducción a la historia universal (Al-Muqaddimah). México, F.C.E. 1987, pág. 315.

51 MIRANDA CALVO, J.: «La ayuda mozárabe en la Reconquista de Toledo», en Toledo Hispanoárabe. Toledo, 1986, pág. 154. 
Muchos mozárabes ante la intransigencia de los alfaquíes intentaron evitar la discriminación aceptando las modas, costumbres y culturas musulmanas. Pero ante este grupo, surge otro que lo que intenta es reafirmar su personalidad, acentuando los rasgos que le diferencian, profundizando en los libros sagrados y realizando una gran labor de proselitismo, lo que provocará que Eulogio y Álvaro de Córdoba se levanten frente a la creciente islamización de los mozárabes, e instan a sus correligionarios a hacer profesión pública de su fe y a combatir la religión islámica.

Aunque Abd al-Rahman II trató de frenar este conflicto, los mártires fueron creciendo durante los meses de junio a noviembre del año 851. De tal forma, que se convocó, el siguiente año, un Concilio en Toledo en el que se prohibió a los cristianos buscar el martirio por cuanto equivalía al suicidio prohibido por Dios. Tampoco fue eficaz la política conciliadora llevada a cabo por Muhammad I que mandó liberar a todos los detenidos, pues los mozárabes dirigidos por Eulogio mantuvieron su actitud de desafío y sus ataques al Islam. El emir ordenó destruir el monasterio de Tábanos, refugio cordobés y centro de los provocadores; detuvo a Eulogio, a quien los toledanos habían elegido metropolitano como un desafío al poder cordobés, y lo hizo ejecutar en el año 859. Con su muerte finalizó la exaltación mística que tanto daño había causado en la convivencia entre cristianos y musulmanes.

Sabemos que en época de Abd al-Rahman III hubo mozárabes influyentes a los que el califa encomendó delicadas misiones, como fue el caso del obispo Recemundo quien fue el encargado de presidir una embajada enviada por el califa a Otón de Alemania; también se le encomendó la misión de viajar a Siria y a Constantinopla para comprar objetos de arte para la nueva residencia del califa en Madinat al-Zahra; e incluso, redactó para al-Hakam II el "Calendario de Córdoba» en el que se indicaban los trabajos campesinos de cada época del año y se daban numerosas precisiones sobre la vida rural y sobre la comunidad mozárabe.

En la realidad, según los jurisconsultos musulmanes, cristianos y musulmanes debían de vivir separados, evitando cualquier trato y conversación entre ellos, recordando uno de los dichos atribuidos a Mahoma que dice: «Yo reniego de todo musulmán que habite dentro de los muros de los politeístas". Se les indica que no deben pedir consejo ni hacer vida común con los cristianos, literalmente «no pidáis ni luz ni lumbre a los politeístas».

Los mozárabes solían vivir en los arrabales de las ciudades, mientras que muchos musulmanes se situaron en aldeas o campiñas como lo hicieron los árabes de Toledo o Sevilla, o poniendo el centro de la administración y la residencia sus gobernadores en poblaciones de menor importancia, pero menos peligrosas ${ }^{52}$. De ello da testimonio la crónica Albelda cuando dice que en los pactos ajustados

52 Los árabes mostraron cierta aversión hacia las antiguas capitales por ser asimismo Sedes episcopales, por esta razón los árabes de Toledo prefirieron habitar en los campo próximos a la ciudad. SIMONET, F.J. Op. Cit., tomo I, pág. 134. 
en el año 718 se convino que las ciudades quedasen desmanteladas y los cristianos habitasen en pueblos y aldeas, como sucedió en Córdoba, Tarazona o Segovia.

Ningún cristiano debería levantar su casa con mayor altura que la de los musulmanes, ni tener vistas sobre ellas. Si sus casas fueran de la misma altura, dijo un alfaquí, habría que demolerlas hasta que quedasen más bajas que las de los fieles creyentes pues esto se ajusta a lo que dijo el Profeta: «El Islam predomina, y así nada se elevará sobre él’ ${ }^{53}$.

El concepto que se tenía de los mozárabes a comienzos del siglo XII, a juzgar por las palabras de Ibn 'Abdun, no era bueno, ya que se les indica a los musulmanes que no vendiesen libros de ciencia, a excepción de los que tratasen de su ley, ni a cristianos ni a judíos, porque «luego traducen los libros y se los atribuyen a los suyos y a sus obispos, siendo que se trata de obras de autores musulmanes». Para este autor, «los mozárabes no tenían buenos sentimientos por lo que debía evitarse que un médico judío o cristiano se dedicase a curar a los musulmanes, porque a quién no tiene simpatía por los musulmanes ¿cómo se les va a confiar la vida?» ${ }^{4}$

\section{CONCLUSIÓN}

Aunque ya durante los siglos IX y $\mathrm{X}$ muchos mozárabes emigraron a la España cristiana huyendo del poder musulmán y formaron grupos de población diferentes al resto de la población cristiana, cuyas relaciones habría que estudiar en profundidad ${ }^{55}$; fue a finales del siglo XI cuando la situación de los mozárabes que residían en al-Andalus empeora extraordinariamente, debido, según la tesis tradicionalista, a la fanática intolerancia de los alfaquíes durante el gobierno de los Almorávides; o probablemente, según estudios recientes, a una serie de factores internos, inherentes a las comunidades cristianas de al-Andalus ${ }^{56}$.

De cualquier forma, en 1126 el emir almorávide Alí ben Yusuf decretó que los mozárabes de al-Andalus fuesen trasladados a Marruecos, quedando con esta medida prácticamente extinguida la población mozárabe de la España musulmana, sin que podamos afirmar que hasta ese momento hubiese existido entre ellos una fluida y apacible convivencia, sobre todo si tenemos presente los reiterados dictámenes jurídicos emitidos sobre el tipo de relación que habían de tener entre ellos,

53 Citado por Al-Bujari, en Compilación de tradiciones muslímicas. Tomado de F. SIMONET, Op. Cit, pág. 81.

54 GARCÍA GÓMEZ, E. y LÉVI-PROVENÇAL, E.: Op. Cit. págs. 172-173.

55 Los mozárabes que emigraron a la España cristiana dejaron sentir ciertas influencias musulmanas tanto en los nombres como en la vestimenta, en las costumbres como en las actividades mercantiles con el establecimientos de mercados fijos a los que estaban acostumbrados en al-Andalus. Algunas tiendas que existían en Zamora o León en el siglo X pertenecían a los mozárabes.

56 GARCÍA SAN JUAN, A.: «El fin de las comunidades cristianas de al-Andalus (s. XI-XII)», XI Congreso de Estudios Medievales, León, 2007. 
o este otro dictamen recogido por al-Wansarisi, muy significativo, en el que se hace hincapié en que «la práctica de intercambiar regalos entre cristianos y musulmanes en la fiesta de Navidad es contraria a la religión", aunque después se añade que "los musulmanes celebran el domingo y el sábado y no trabajan estos días ni en las fiestas cristiana ${ }^{57}$, o aquél otro precepto en el que se prohíbe a los musulmanes tener trato y estrechar lazos de amistad, como señalamos anteriormente, con los dimmíes por considerarlos enemigos religiosos, pues así se contempla en El Corán, Sura 5, 57 « ¡Creyentes! No toméis como amigos a quienes habiendo recibido la «Escritura» antes que vosotros, toman vuestra religión a burla y a juego, ni tampoco a los infieles. ¡Temed a Dios, si sois creyentes!». Y en otro lugar, vr. 80 se dice: "Ves a muchos de ellos (musulmanes) que traban amistad con los que no creen. Lo que han hecho antes está tan mal que Dios está irritado con ellos y tendrán un castigo eterno» ${ }^{58}$.

Prueba evidente de lo complejas y difíciles que debieron de ser, en determinadas épocas, las relaciones entre musulmanes y cristianos que vivieron en al-Andalus, y entre éstos y sus correligionarios que vivieron en la España Cristiana.

57 PEÑARROJA TORREJÓN, L.: Op. Cit. pág.57.

${ }^{58}$ EL CORÁN, Op. Cit. págs. 185-188. 